\title{
Coral-feeding fishes slow progression of black-band disease
}

Received: 2 March 2009/Accepted: 25 May 2009/Published online: 12 June 2009

(C) Springer-Verlag 2009

Outbreaks of coral disease are a major contributor to coral mortality and subsequent reef degradation (Weil et al. 2006). One of the most common coral diseases on the Great Barrier Reef (GBR) is black-band disease. This disease forms a distinctive band which marks the interface between live, healthy tissue and dead coral skeleton (Fig. 1). If, as has been suggested, corallivorous fishes act as transmission vectors of disease (e.g., Aeby and Santavy 2006), they must feed directly upon the infected area. This direct feeding may actually be beneficial as it could lessen the extent and progression of the disease. In fact, it is conceivable that under intense or preferential predation on diseased tissue that the infecting agent could be removed and coral health promoted.

At Lizard Island on the GBR, six species of coral-feeding fishes Chaetodon baronessa,

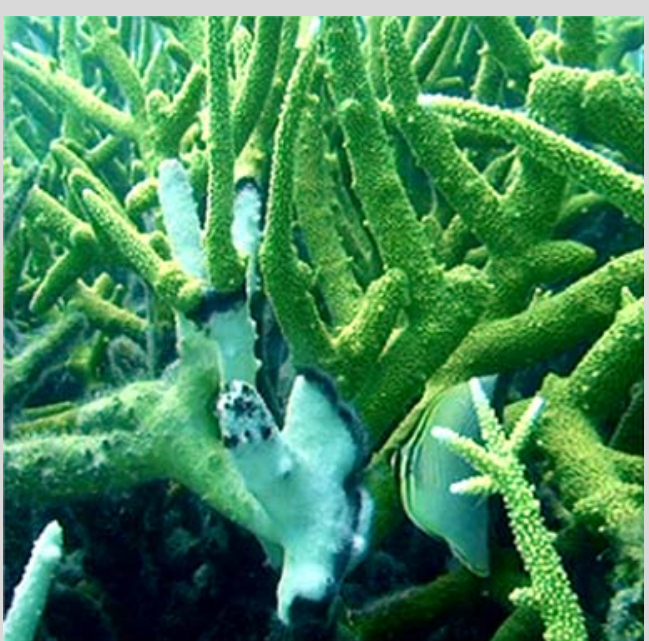

Fig. 1 Chaetodon baronessa feeding on black-band disease under natural conditions

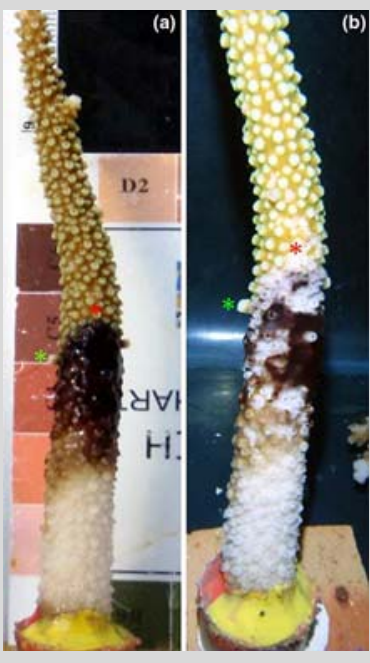

Fig. 2 Acropora muricata nubbins infected with black-band disease a before predation and $\mathbf{b}$ after predation by $C$. plebius. Asterisks mark common points in the two photos sion of this disease. After $1 \mathrm{~h}$ of feeding the diseased band had been partially removed (Fig. 2) and thereafter the band failed to progress along the branch over the next $48 \mathrm{~h}$. In control nubbins, however, the disease continued to progress along coral branches at a rate of $1.1 \mathrm{~mm} \mathrm{~h}^{-1}$ and resulted in the mortality of these nubbins. While ongoing experiments are yet to show that corallivorous butterflyfishes contribute to the spread of coral disease, these fishes may be essential in reducing the incidence and severity of black-band disease on the GBR.

Acknowledgements The authors thank the Wildlife Preservation Society of Australia, Australian Geographic and Project AWARE Foundation for financial support. Comments from the two anonymous reviewers greatly improved this manuscript

\section{References}

Aeby GS, Santavy DL (2006) Factors affecting susceptibility of the coral Montastraea faveolata to black-band disease. Mar Ecol Prog Ser 318:103-110

Weil E, Smith G, Gil-Agudelo DL (2006) Status and progress in coral reef disease research. Dis Aquat Organ 69:1-7

A. J. Cole $(\bowtie) \cdot$ M. S. Pratchett · G. P. Jones

ARC Centre of Excellence for Coral Reef Studies, James Cook University, Townsville, QLD 4811, Australia e-mail: andrew.cole3@jcu.edu.au

A. J. Cole $\cdot$ K. M. Chong Seng $\cdot$ M. S. Pratchett $\cdot$ G. P. Jones

School of Marine and Tropical Biology, James Cook University, Townsville, QLD 4811, Australia

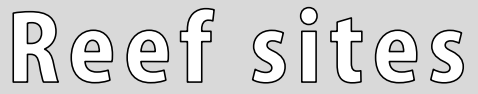

Coral Reefs (2009) 28:965 DOI 10.1007/s00338-009-0519-3 